\title{
Inter-Unit Doctoral Program in Nursing of the University of São Paulo: Characterization of Graduates and Theses Defended in a Decade
}

\author{
Livia Maria Garbin ${ }^{1}$ \\ Ana Lídia de Castro Sajioro Azevedo ${ }^{1}$ \\ Leandra Terezinha Roncolato da Silva ${ }^{1}$ \\ Ana Maria Laus ${ }^{2}$ \\ Lucieli Dias Pedreschi Chaves ${ }^{2}$ \\ Dulce Maria Rosa Gualda ${ }^{3}$ \\ Lídia Aparecida Rossi ${ }^{4}$
}

This descriptive study aimed to characterize the graduates of the Inter-unit Doctoral Program in Nursing of the School of Nursing of the University of São Paulo, who defended their theses in the period 1998-2008, in relation to the location they developed their Masters and their pre and post-doctoral employment, also to investigate the theses defended in relation to the thematic areas and methodological approaches used. Data were collected from the Fenix-USP System and the Lattes Curriculum System. Of the 190 graduates, 178 had curriculums available online. Of those, 58.4\% performed teaching and research activities when they entered the doctoral program, which were activities mainly developed at Federal Universities (34.8\%). This predominance was maintained after the conclusion of the doctoral studies. The thematic areas most studied were Women's Health (20.5\%) and Adults/Elderly Health (13.2\%). Regarding the methodological approach, 68.4\% used qualitative methods. The data evidenced the contributions of this Program to research.

Descriptors: Nursing; Nursing Research; Education, Nursing, Graduate.

\footnotetext{
${ }^{1}$ RN, Master's Student, Escola de Enfermagem de Ribeirão Preto, Universidade de São Paulo, WHO Collaborating Centre for Nursing Research Development, SP, Brazil. E-mail: liviagarbin@usp.br, alsajioro@eerp.usp.br, leandra_enf@yahoo.com.br.

${ }^{2}$ RN, Ph.D. in Nursing, Professor, Escola de Enfermagem de Ribeirão Preto, Universidade de São Paulo, WHO Collaborating Centre for Nursing Research Development, SP, Brazil. E-mail: analaus@eerp.usp.br, dpchaves@eerp.usp.br.

${ }^{3}$ RN, Ph.D. in Nursing, Full Professor, Escola de Enfermagem, Universidade de São Paulo, SP, Brazil. E-mail: drgualda@usp.br.

${ }^{4}$ RN, Ph.D. in Nursing, Full Professor, Escola de Enfermagem de Ribeirão Preto, Universidade de São Paulo, WHO Collaborating Centre for Nursing Research Development, SP, Brazil. E-mail: rizzardo@eerp.usp.br.
}

Corresponding Author:

Livia Maria Garbin

Universidade de São Paulo. Escola de Enfermagem de Ribeirão Preto.

Av. dos Bandeirantes, 3900

Bairro Monte Alegre

CEP: 14040-902 Ribeirão Preto, SP, Brasil

E-mail: liviagarbin@usp.br 


\section{Programa interunidades de doutoramento em enfermagem da Universidade de São Paulo: caracterização dos egressos e teses defendidas em uma década}

Este é um estudo descritivo, cujos objetivos foram caracterizar os egressos do Programa Interunidades de Doutoramento em Enfermagem da Escola de Enfermagem da Universidade de São Paulo e Escola de Enfermagem de Ribeirão Preto, com teses defendidas entre 1998 e 2008, em relação ao local de realização do mestrado, vínculo empregatício anterior e posterior ao doutorado, e investigar as teses em relação às áreas temáticas e abordagens metodológicas utilizadas. Os dados foram coletados no Sistema Fênix-USP e Currículo Lattes de 190 egressos, dos quais 178 tinham currículo disponível online. Desses, 58,4\% realizavam atividades de docência e pesquisa no momento do ingresso no doutorado, atividades essas desenvolvidas principalmente em universidades federais $(34,8 \%)$, predominância que se manteve após o término do doutorado. As áreas temáticas mais estudadas foram saúde da mulher $(20,5 \%)$ e do adulto/idoso $(13,2 \%)$ e $68,4 \%$ utilizaram métodos qualitativos. Os dados evidenciam contribuição desse Programa para a pesquisa.

Descritores: Enfermagem; Pesquisa em Enfermagem; Educação de Pós-Graduação em Enfermagem.

\section{Programa inter-unidades de doctorado en enfermería de la Universidad de Sao Paulo: caracterización de los egresados y tesis defendidas en una década}

Se trata de un estudio descriptivo con el objetivo de caracterizar a los egresados del Programa Inter-unidades de Doctorado en Enfermería de la Escuela de Enfermería de la Universidad de Sao Paulo y Escuela de Enfermería de Ribeirao Preto, con tesis defendidas entre 1998 y 2008, en relación al local de realización de la maestría, vínculo de empleo anterior y posterior al doctorado e investigar las tesis en relación a las áreas temáticas y abordajes metodológicos utilizados. Los datos fueron recolectados en el Sistema FenixUSP y Currículo Lattes de 190 egresados, de los cuales 178 tenían currículo disponible on-line. De estos, 58,4\% realizaban actividades de docencia e investigación en el momento del ingreso en el doctorado, actividades estas desarrolladas principalmente en Universidades Federales (34,8\%); predominancia que se mantuvo después del término del doctorado. Las áreas temáticas más estudiadas fueron Salud de la Mujer $(20,5 \%)$ y del Adulto/Anciano (13,2\%), siendo que 68,4\% utilizaron métodos cualitativos. Los datos colocaron en evidencia la contribución de este Programa para la investigación.

Descriptores: Enfermería; Investigación en Enfermería; Educación de Postgrad en Enfermería.

\section{Introduction}

Until the fifties, research in nursing in Brazil was scarce, most knowledge or information contained in articles was sourced from personal experience, tradition, authority, intuition or borrowed. Circumstances brought the need for research(1), which, among other things, culminated in the development of the post-graduation in nursing in Brazil.
Currently, the post-graduation in nursing is a consolidated segment of Brazilian education, contributing to the formation of qualified human resources, guaranteeing an outstanding position for Brazil in the Latin American context due to the scientific development that occurred. The consolidation of postgraduate education was a determining factor for the development of Brazilian nursing(2). 
The development of the Brazilian post-graduation stricto sensu was established in 1968 with the University Reform $^{(2)}$, and in the 70s, post-graduate nursing had grown to eight Masters courses across several regions of the country.

The Inter-unit Doctoral Program in Nursing, created and maintained in a joint effort by the School of Nursing (EE) and the School of Nursing of Ribeirão Preto (EERP), University of São Paulo (USP), in 1982, was the first post-graduate doctorate level program in nursing in Latin America. It was jointly planned by both institutions, with the intention to combine efforts aimed at the maximum utilization of their respective potentials in terms of faculty, facilities and conditions for research in the field of nursing(3). The purpose of the program was to attend to the need for training nurses at the doctoral level; but from 2007, began to accept other professionals interested in scientific education in the health area, reflecting the characteristics of a multidisciplinary program, which aims to "provide a thorough scientific training for researchers in the health area in order to develop technical, scientific and ethicalpolitical skills in research, care and education"(4).

In spite of the current paradigms and their trends in evaluation of the scientific production, the contribution of a Program of this size is undeniable for the construction of knowledge in the area of nursing; both from the standpoint of the production itself, represented by the theses defended as the conclusion of the course work, the training of human resource multipliers of knowledge and the qualification of professionals for the development of research activity ${ }^{(5)}$.

Furthermore, nursing has sought, in research, the instruments to ensure its field of work and to configure its own knowledge ${ }^{(5)}$, and the need to perform an evaluation of scientific literature in order to verify its contribution in the health area has been identified, with increasing emphasis.

In this context, a look at the research that constituted the theses of the doctoral students of the Inter-unit Program provides a reflection on the contribution of these studies to the knowledge of nursing and its evolution, and establishes guidelines on the current trends observed in the research developed in this area.

\section{Objectives}

To characterize the graduates of the Inter-unit Doctoral Program in Nursing of the University of São
Paulo who defended their theses in the period 19982008 , in relation to the location they developed their Masters, pre and post-doctoral employment situations, and to investigate the theses defended in relation to the thematic areas and methodological approaches used.

\section{Methodology}

This is a descriptive, quantitative study. For the identification of students and their defended theses in the period of interest, a list obtained from the Fenix System $^{(6)}$ of the USP was used. This system is an initiative that allows students and professors to develop online the semester registration process in postgraduation, in an integrated manner in the different units of the USP.

Data collection of the characterization of the graduated students was conducted using the Lattes Curriculum System available online from the National Council for Scientific and Technological Development $(\mathrm{CNPq})^{(7)}$, which is public domain. For the location of the curriculum the name of the author of the thesis was used.

Abstracts of the defended theses were located in the Center for Bibliographic Support of the EERP in the Theses and Dissertations in Nursing Catalogs of the Brazilian Nursing Association - ABEn ${ }^{(8-9)}$, in the database LILACS (Latin American and Caribbean Health Sciences Information Center ) and the Digital Library of Theses of the USP.

To collect data an instrument was developed containing the following items: the thesis defense date, author, title of thesis, aim of study, thematic area and methodological approach used; date of Lattes Curriculum update, institution where the Masters was developed, activities performed at the time of entry into the doctorate course and after finishing, and the respective institutions of employment. Regarding the activities, the following information was sought in the Lattes Curriculum: professional activities, projects and scientific production. The activities performed by subjects were categorized as teaching, care and research. In the process of data collection, the date of entry and completion of the doctoral course were considered in order to categorize activities before and after the doctorate.

The objects of the study were grouped into thematic areas developed for this purpose in a previously conducted study which was based on information available in reports from CAPES - Coordination for the 
Improvement of Higher Education Personnel. For the elaboration of thematic areas the traditional conception of areas of nursing knowledge was considered(5): Child and Adolescent Health, Women's Health, Collective Health, Mental and Psychiatric Health, Education, Management, Adult/Elderly Health, Occupational Health, Information and Communication, and Others. The studies were grouped according to these areas and those that did not fit into any of them were inserted into the category Others.

For the data analysis the Statistical Package for Social Science (SPSS for Windows, release 15.2006. Chicago: SPSS Inc.) was used.

\section{Results}

From the survey conducted in the Fenix System ${ }^{(6)}$, it was found that there were 190 doctoral theses defended in the Program during the period of interest.

Regarding the characterization of the students of the Program, 178 (93.7\%) were found in the Lattes Curriculum site of CNPq, and among these, 159 $(89.3 \%)$ had updated their curricula in the years 2008 and 2009.

These students developed their Masters in federal universities $(44.4 \%)$, state universities (16.3\%), and private institutions $(3.9 \%)$. In $63(35.4 \%)$ cases this information could not be verified.

In relation to activities performed by students at the time of entering the doctorate, a wide variation was found, since they were active in teaching or care only, the two together, or related with research activities. A predominance of the development of teaching and research activities together (58.4\%) was observed, and these activities were developed mainly in Federal Universities as in $34.8 \%$ of cases. When the nurses performed care activities (17.4\%) combined or not with activities of teaching and research, they were developed mainly in public health institutions (74.2\%). It is emphasized that at this time, 105 (58.9\%) professionals were enrolled in research activities in parallel with teaching activities or care.

With regard to activities and institutions in which the graduated students are currently involved, variation was also observed, again with the predominance of the joint activities of teaching and research (67.4\%) and the development of these activities in public universities (43.2\%). Based on the institution of work, as well as activities described in the item professional experience of the Lattes curriculum, development of research projects and scientific production, it was found that the number of professionals involved in research activities in conjunction with other activities or not increased from $58.9 \%$ to $68.5 \%$ after completion of the doctorate. It is emphasized that among professionals (6.2\%) who exclusively developed care activities, only $2.8 \%$ remained acting solely in these activities after their doctorate.

For the analysis of the theme and methodology employed, the abstracts of the defended theses were used, which were located in the Center for Bibliographic Support of the EERP (15.8\%) in the Theses and Dissertations in Nursing Catalogs ABEn (64.2\%)(8-9), in the LILACS database (3.2\%) and the Digital Library of Theses of the USP (16.8\%). The data were analyzed and grouped by every two years aiming at a clearer presentation.

Table 1 presents the distribution of students entered in the Program and of theses defended grouped by year. The period from 1998 to 2001 shows a significant number of defenses, which occurs mainly in 1999 with a total of 39 theses defended (20.5\%) also the number of entrants in the Program is also higher in this period. From 2002 a decline in these numbers was observed.

Table 1 - Distribution of students entered and theses defended in the Inter-unit Doctoral Program in Nursing EE-EERP/USP grouped by year. Ribeirão Preto, 2009

\begin{tabular}{ccc}
\hline Year & Entrants in the Program $\mathbf{n}(\%)$ & Theses defended $\mathbf{n}(\%)$ \\
\hline 1998 & $20(13.9)$ & $16(8.4)$ \\
1999 & $12(8.4)$ & $39(20.5)$ \\
2000 & $15(10.5)$ & $20(10.5)$ \\
2001 & $22(15.4)$ & $22(11.6)$ \\
2002 & $12(8.4)$ & $15(7.9)$ \\
2003 & $06(4.2)$ & $15(7.9)$ \\
2004 & $12(8.4)$ & $15(7.9)$ \\
2005 & $11(7.7)$ & $18(9.5)$ \\
2006 & $08(5.6)$ & $10(5.3)$ \\
2007 & $11(7.7)$ & $06(3.1)$ \\
2008 & $14(9.8)$ & $14(7.4)$ \\
Total & $143(100)$ & $190(100)$ \\
\hline
\end{tabular}

Source: Fenix System of the University of São Paulo, 2009

The identification of thematic areas (Table 2) was based, in a first instance, on the areas that the objects of the research study focused on, just as they were presented, or those which they were closest to, since 
some abstracts were not clearly explicit regarding the object or even the justification of research. Thus, the 190 theses were distributed in the ten thematic areas previously mentioned. The need to include the category Others occurred since, in some cases, it was not possible to include the studies in the traditional areas of nursing knowledge. It is possible to observe that areas that included the largest number of theses, over the ten years, were Women's Health (20.5\%), Adult and Elderly Health (13.2\%), Education (12.6\%), Management (10.5\%) and Child and Adolescent Health $(10.0 \%)$.

Table 2 - Distribution of theses defended in the Inter-unit Doctoral Program in Nursing EE-EERP/USP grouped by year and thematic area. Ribeirão Preto, 2009

\begin{tabular}{|c|c|c|c|c|c|c|c|}
\hline \multirow{2}{*}{ Thematic Area } & \multicolumn{7}{|c|}{ Period } \\
\hline & $\begin{array}{c}1998-1999 \\
n(\%)\end{array}$ & $\begin{array}{c}2000-2001 \\
n(\%)\end{array}$ & $\begin{array}{c}2002-2003 \\
n(\%)\end{array}$ & $\begin{array}{c}2004-2005 \\
\text { n (\%) }\end{array}$ & $\begin{array}{c}2006-2007 \\
\text { n (\%) }\end{array}$ & $\begin{array}{l}2008 \\
\text { n (\%) }\end{array}$ & $\begin{array}{l}\text { Total } \\
\text { n (\%) }\end{array}$ \\
\hline Child and Adolescent Health & $06(10.9)$ & $03(7.2)$ & $04(13.3)$ & $04(12.2)$ & 0 & $02(14.3)$ & $19(10.0)$ \\
\hline Women's Health & $11(20.0)$ & $11(26.2)$ & $05(16.7)$ & $07(21.2)$ & $02(12.5)$ & $03(21.4)$ & $39(20.5)$ \\
\hline Collective Health & $04(7.3)$ & $04(9.5)$ & $01(3.3)$ & $04(12.1)$ & 0 & $01(7.2)$ & $14(7.4)$ \\
\hline Mental and Psychiatric Health & $04(7.3)$ & $04(9.5)$ & $05(16.7)$ & $03(9.1)$ & $01(6.3)$ & 0 & $17(8.9)$ \\
\hline Education & $05(9.1)$ & $04(9.5)$ & $05(16.7)$ & $06(18.2)$ & $04(25.0)$ & 0 & $24(12.6)$ \\
\hline Management & $07(12.7)$ & $04(9.5)$ & $03(10.0)$ & $02(6.0)$ & $02(12.5)$ & $02(14.3)$ & $20(10.5)$ \\
\hline Adult and Elderly Health & $06(10.9)$ & $07(16.6)$ & $02(6.7)$ & $04(12.2)$ & $03(18.7)$ & $03(21.4)$ & $25(13.2)$ \\
\hline Occupational Health & $02(3.6)$ & $03(7.2)$ & $03(10.0)$ & $01(3.0)$ & $03(18.7)$ & $03(21.4)$ & $15(7.9)$ \\
\hline Information and Communication & $02(3.6)$ & 0 & $01(3.3)$ & 0 & 0 & 0 & $03(1.6)$ \\
\hline Others* & $08(14.6)$ & $02(4.8)$ & $01(3.3)$ & $02(6.0)$ & $01(6.3)$ & 0 & $14(7.4)$ \\
\hline Total & $55(100)$ & $42(100)$ & $30(100)$ & $33(100)$ & $16(100)$ & $14(100)$ & $190(100)$ \\
\hline
\end{tabular}

*1998-1999: 03 theoretical reviews, 01 study with animals, 02 studies on ethics and 03 on professional identity; 2000-2001: 02 studies on professional identity; 2002-2003: 01 study on professional identity; 2004-2005: 01 theoretical review and 01 study on professional identity; 2006-2007: 01 study on professional identity

Source: Abstracts of theses defended in the Inter-unit Doctoral Program in Nursing in the period from 1998 to 2008

The Others category accounted for 14 theses $(7.4 \%)$, and included theses that addressed the issues: ethics (2), theoretical reviews (3) professional identity (8), and experimental study developed with animals (1), completed in 1998.

In the first stage of the study, here defined as the period from 1998 to1999, 55 theses were defended. The areas of Women's Health (20.0\%) and Management (12.7\%) were the most studied, followed by Child and Adolescent Health and Adult and Elderly Health, both accounting for $10.9 \%$. In the period corresponding to the years 2000-2001, the frequency presented evidence that the area of Women's Health was maintained with a percentage close to previous years with 11 theses (26.2\%), continuing to be the most frequent theme, followed by Adult and Elderly Health $(16.6 \%)$. All other areas maintained similar percentages to the previous period.

By visualizing the period 2002-2003, the thematic areas more frequently developed were Women's Health, Mental and Psychiatric Health and Education (16.7\% each). In the period 2004-2005, 33 theses were defended, when once again the area of Women's Health (21.2\%) predominated.

There was a decline in the number of defenses in the period 2006-2007, with the area of Education (25.0\%) predominant. In 2008, 14 theses were defended, and Women's Health, Adult and Elderly Health, and Occupational Health presented the same frequency of defenses (21.4\% each). The area where fewer studies were developed was Information and Communication, and in most periods there was no production on this theme.

The distribution of the theses, according to the methodological approach used in this study, can be seen in Table 3. It was verified that 130 (68.4\%) of the theses analyzed used a qualitative approach. 
Table 3 - Distribution of theses defended in the Inter-unit Doctoral Program in Nursing EE-EERP/USP grouped by year and methodological approach. Ribeirão Preto, 2009

\begin{tabular}{|c|c|c|c|c|c|c|c|}
\hline \multirow[b]{2}{*}{ Methodological approach } & \multicolumn{7}{|c|}{ Period } \\
\hline & $\begin{array}{c}1998-1999 \\
\text { n (\%) }\end{array}$ & $\begin{array}{c}2000-2001 \\
n(\%)\end{array}$ & $\begin{array}{c}2002-2003 \\
\text { n (\%) }\end{array}$ & $\begin{array}{c}2004-2005 \\
\text { n (\%) }\end{array}$ & $\begin{array}{c}2006-2007 \\
\text { n (\%) }\end{array}$ & $\begin{array}{l}2008 \\
\text { n (\%) }\end{array}$ & $\begin{array}{l}\text { Total } \\
\text { n (\%) }\end{array}$ \\
\hline Quantitative & $16(29.1)$ & $10(23.8)$ & $06(20)$ & $09(27.3)$ & $05(31.3)$ & $09(64.3)$ & $55(29.0)$ \\
\hline Qualitative & $38(69.1)$ & $31(73.8)$ & $23(76.7)$ & $23(69.7)$ & $11(68.7)$ & $04(28.5)$ & $130(68.4)$ \\
\hline Mixed method & $01(1.8)$ & $01(2.4)$ & $01(3.3)$ & $01(3.0)$ & 0 & $01(7.2)$ & $05(2.6)$ \\
\hline Total & $55(100)$ & $42(100)$ & $30(100)$ & $33(100)$ & $16(100)$ & $14(100)$ & $190(100)$ \\
\hline
\end{tabular}

Source: Abstracts of theses defended in the Inter-unit Doctoral Program in Nursing in the period from 1998 to 2008

Quantitative studies totaled 55 theses (29.0\%) and maintained constant oscillations in this period. However, it was observed that in the year 2008, there was a sudden reversal, with nine theses (64.3\%) based on the quantitative approach. Only five studies (2.6\%) combined the qualitative and quantitative methods.

\section{Discussion}

Since its accreditation in 1982 through to the end of 2008, 346 nurses have graduated from the Program, who now form a critical mass in their institutions of origin, creating new post-graduate courses, and who are leaders of new research centers and centers of study in healthcare institutions and higher education in the country and in Latin America(4,10-11).

Besides the academic and administrative influence of the Program, nursing care also benefits, as the graduates working in health institutions, can transfer the acquired knowledge to the practice of healthcare, consolidating research as an activity of the nurse ${ }^{(5)}$.

One factor that may have led to decreased numbers of entrants from 2002 is that this Program was the first to offer the doctorate course, which contributed to the formation of many students who had attended the Masters course and had been waiting to continue their training. In the 90s, several other courses were created, concentrated in the southeast region, which led the students to seek other programs according to their needs and availability.

In 2007, there was a reduction in the number of defenses due to the decreased entry of students in 2003 consequently there was a decrease in the proportion of postgraduate students in relation to the size of the faculty. However, with the beginning of the continuous selection process in 2006(10), there was an increased demand for the Program, which resulted in an increase in the number of defenses in 2008 and of entrance of students, which was also expected for 2009. Despite these fluctuations in the arrival of new students, it was observed that their characteristics (active in teaching and research especially in the Federal Institutions of Higher Education) were maintained.

Regarding the thematic areas, it is emphasized that only one experimental study with animals was developed, there were no others because they are not related to the proposal of the Program. Evolution in the development of research according to the thematic area was verified and that the areas of Women's Health, Management, Adult Health / Elderly and Occupational Health, although having a varying frequency to each other and over the years, maintained a regularity of development of studies.

It is striking that in the periods from 1998 to 2003, the area of Mental and Psychiatric Health had a greater number of theses defended, which may be associated with the psychiatric reform movements started in the 1980 s and 1990s and the enactment of the Mental Health Act in April 2001(12).

The area of Education continued throughout the interval studied a periodicity of constant production, which can be justified because of the accentuated discussions and revisions of the curricula of undergraduate courses of the schools of nursing, supporting the proposal to reformulate the basic curriculum of the time, reinforcing the need for critical and reflective training of nurses stimulated toward the development of the scientific spirit.

The data presented in relation to the methodological approach confirms the growing trend of qualitative studies in nursing, which has been occurring since the $80 \mathrm{~s}$, as evidenced in other studies ${ }^{(5,13)}$. The positivist method prevailed until the end of the first decade of the Program, and in 1999 a point of inflection appeared and the qualitative method became more regularly and continuously used in research(5). A previous study ${ }^{(5)}$ marks an important milestone as the $1^{\text {st }}$ Inter-American Meeting of Qualitative Research in Nursing, promoted by professors of the EE-USP and the Nursing Department of the Federal University of Santa Catarina, which would 
have significantly influenced the nurses in the definition and perception of objects of study, indicating new methodological approaches. From there, it was observed that the difference between the two approaches became increasingly large, with a predominance of qualitative methods from the $90{ }^{\prime} s^{(5)}$. In the context of qualitative methodology applied to health, it is not sought to study the phenomenon itself, but to understand the individual or collective significance to people's lives ${ }^{(14)}$.

As evidenced in this survey, in a study which analyzed all the production of theses in Brazil from 1983 to $2001^{(13)}$, only five $(1.1 \%)$ used a combination of quantitative and qualitative methods and, according to the authors, without demonstrating a clarity of the purpose of triangulation to the wider domain or a deepening of the knowledge about the object of study.

\section{Final considerations}

Brazilian post-graduation has grown significantly in recent years, acquiring a position of prominence in the higher education system. It is verified that some thematic areas are covered more evenly over time, but others, such as Education, are closely related to the moment, such as organizational and policy changes.

The results demonstrated the prevalence of the interpretive paradigm in the process of knowledge construction during the study period. The qualitative approach opens the eyes to the comprehension of social phenomena and deepens the understanding of the realities that permeate the practices of nursing.

It was observed that a contribution arising from the research has been produced and needs to be incorporated in the daily practices of institutions linked to health, and that this Program contributes significantly to the production of knowledge.

Although some interesting information was obtained by analyzing the abstracts, the importance of this production for the academic environment cannot be affirmed and it may be interesting to verify and prove the effectiveness of these results in practice.

The theories and knowledge generated from nursing research are fundamental for establishing a scientific basis for planning, prediction and control of the results of practice. The use of research will yield more credibility for the nurse as a specialist in nursing care and will provide more efficiency in the making of decisions.

This work contributed to the increase of data presented in a previous study, in relation to the thematic areas studied and methodologies used in the thesis developed, and gives an overview of the activities performed by graduates of the Inter-unit Program. From this overview, it is possible to observe that this Program remains a reference in the formation of doctors (professors and researchers) that work in various institutions of higher education in the country. It also shows the important contribution that the characterization of graduates can give, as an indicator for the evaluation of post-graduate courses primarily in relation to the doctorate.

Besides the aspects evaluated in this study, others should be considered for the analysis of performance of post-graduation programs such as: the evaluation of the impact of the formation of professors for the consolidation of research centers/groups and of the socio-economic impact of their products.

\section{References}

1. Mendes IAC. Pesquisa em Enfermagem. São Paulo (SP): EDUSP; 1991.

2. Almeida $M C P$, Rodrigues RAP, Furegato ARF, Scochi CGS. A pós-graduação na Escola de Enfermagem de Ribeirão Preto-USP: evolução histórica e sua contribuição para o desenvolvimento da enfermagem. Rev. Latino-Am. Enfermagem. 2002; 10(3):276-87. 3. Ferriani MGC, Silva IA, Carvalho EC. A trajetória histórica do Programa Interunidades de doutoramento em enfermagem e sua contribuição para enfermagem brasileira. Rev Esc Enferm USP. 2005; 39(Esp):506-14.

4. Universidade de São Paulo. Escola de Enfermagem de Ribeirão Preto. Doutorado Interunidades EE-EERP / USP [Internet]. São Paulo, Ribeirão Preto: Escola de Enfermagem, Escola de Enfermagem de Ribeirão Preto. Programa Interunidades de Doutoramento em Enfermagem da Escola de Enfermagem e Escola de Enfermagem de Ribeirão Preto; [Acesso 21 maio 2009]. Disponível em: http:// www2.eerp.usp.br/pg/pdiu.php
5. CAPES: Coordenação de aperfeiçomento de pessoal de nível superior [Internet]. Brasília: Ministério da Educação. Resultados da Avaliação; 2007 (Triênio 2004/2006). [Acesso 21 maio 2009]. Disponível em: http://conteudoweb.capes.gov.br/conteudoweb/Av aliacaoTrienalServlet?ano $=2006 \&$ acao $=$ pesquisar\&IES $=\&$ Area $=20$ 6. Silva IA, Ferriani MGC, Carvalho EC. Programa Interunidades de Doutoramento em Enfermagem: 21 anos construindo ciência. Rev Esc Enferm USP. 2005; 39(Esp):515-21.

7. Universidade de São Paulo (BR). Fênix Web: Sistema de pósgraduação [Internet]. São Paulo: Universidade de São Paulo; [Acesso 15 jan 2009]. Disponível em: https://sistemas.usp.br/ fenixweb/

8. Ministério da Ciência e Tecnologia (BR). Conselho Nacional de Desenvolvimento Científico e Tecnológico. Plataforma Lattes [Internet]. Conselho Nacional de Desenvolvimento Científico e Tecnológico; [Acesso fev 2009]. Disponível em: http://lattes. cnpq.br/ 
9. ABEn: Associação Brasileira de Enfermagem [Internet]. Brasília: ABEn. Dissertação de Tese/Dissertação Online: Instruções para divulgação online da tese/dissertação na forma de texto completo; [Acesso 20 jan 2009]. Disponível em: http:// www. abennacional.org.br/index.php?path $=140$

10. Associação Brasileira de Enfermagem. Catálogo de Teses e Dissertações em Enfermagem - Volume 1-18, 1979-2000 [CDROM]. Brasília: Associação Brasileira de Enfermagem; 2000.

11. Paravic T. Postgrado stricto sensus del departamento de la Universidad de Concepción, Chile. Rev. Latino-Am. Enfermagem. 2004;12(6):946-53.
12. Tenório F. A reforma psiquiátrica brasileira, da década de 1980 aos dias atuais: história e conceito. Hist Cienc SaudeManguinhos. 2002; 9(1):25-59.

13. Erdmann AL, Silva IA, Rodrigues RA, Fernandes JD, Viana LAC, Lopes MJM, et al. Teses produzidas nos programas de PósGraduação em Enfermagem de 1983 a 2001. Rev Esc Enferm USP. 2005; 39(Esp):497-505.

14. Turato ER. Métodos qualitativos e quantitativos na área da saúde: definições, diferenças e seus objetos de pesquisa. Rev Saúde Pública. 2005; 39(3):507-14. 